\title{
Agenesis of the Dorsal Pancreas
}

\author{
Varun Manoharan ${ }^{1,2,3}$, Minoli Vinoda Abeysekera ${ }^{1,2,4}$, Emily Hibbert $^{1,2}$ \\ ${ }^{1}$ Department of Endocrinology, Nepean Hospital, Penrith, NSW, Australia; ${ }^{2}$ Nepean Clinical School, Faculty of Medicine and \\ Health, The University of Sydney, NSW; ${ }^{3}$ South Western Sydney Clinical School, University of New South Wales, Sydney, NSW; \\ ${ }^{4}$ Griffith Medical School, Griffith University, Gold Coast, Queensland.
}

\section{Corresponding Author: \\ Dr Varun Manoharan \\ Email: manoharan.varun@hotmail.com}

This is an Open Access article distributed under the terms of the Creative Commons Attribution License (creativecommons.org/ licenses/by/3.0).

Received : November 2, 2020

Accepted : May 1,2021

Published : June 5,2021

\begin{abstract}
Background: Agenesis of the dorsal pancreas (ADP) is a rare entity, which is often diagnosed incidentally on abdominal imaging. It can present with abdominal pain or with symptoms of exocrine and endocrine deficiency. Approximately half of patients with ADP will have a diagnosis of diabetes mellitus, and up to half of them will require insulin therapy. Case Report: Abdominal CT in a 39-year-old man with antibody negative type 1 diabetes and chronic abdominal pain revealed dorsal pancreatic agenesis without any focal pancreatic lesions or evidence of pancreatitis. An MRCP showed normal hepatobiliary anatomy. He was replete for fat soluble vitamins. Investigations at the time of diabetes diagnosis demonstrated relative insulin deficiency. Conclusion: The case highlights that ADP is a rare cause of abdominal pain, which is often diagnosed incidentally on abdominal imaging.
\end{abstract}

Keywords: Abdominal Pain; Diabetes Mellitus; Insulin; Pancreas Agenesis; Vitamins.

\section{Introduction}

In parallel with improvement in imaging technologies, there has been an increase in the frequency of incidental diagnosis of agenesis of the dorsal pancreas. Yet this congenital malformation remains rare; its manifestations include diabetes mellitus, abdominal pain and pancreatitis [1]. We report a case of a 39-year-old man with antibodynegative type 1 diabetes and abdominal pain, who was incidentally found to have dorsal agenesis of the pancreas on abdominal CT performed to investigate his chronic abdominal pain.

\section{Case Report}

A 39-year-old Caucasian man from nonconsanguineous kinships presented to the Diabetes Service in 2020 for ongoing management of his type 1 diabetes mellitus. He reported long standing colicky epigastric pain associated with intermittent diarrhea without any blood or mucus in his stools. His abdominal pain was exacerbated by fatty meals. He reported significant loss of appetite but denied any extra-intestinal symptoms suggestive of inflammatory bowel disease. His drug and alcohol history were unremarkable.

He was diagnosed with antibody negative type 1 diabetes mellitus three years prior, when he presented with polyuria, polydipsia and unintentional weight loss. Further investigations performed at diagnosis showed a relative insulin deficiency with a C-peptide level of $1.0 \mu \mathrm{g} / \mathrm{L}$ [0.8-3.4], fasting serum insulin level of $6 \mathrm{mu} / \mathrm{L}$ $[<10]$ with a paired random plasma glucose level of $27.1 \mathrm{mmol} / \mathrm{L}$ and $\mathrm{HbA} 1 \mathrm{c}$ of $9.6 \%$ [Table 1]. Autoantibodies for glutamic acid decarboxylase, islet cell, insulin and zinc transporter 8 were not detected. However, he had other features of autoimmunity. He was sub-clinically hypothyroid [Table 1] with elevated thyroid peroxidase antibody $>1300 \mathrm{U} / \mathrm{mL}$ $[<60]$. His celiac serology was negative and he had a vitamin $B_{12}$ level of $205 \mathrm{pmol} / \mathrm{L}$ [150 pmol/L]. A diagnosis of Hashimoto's thyroiditis and 
Table 1: Preliminary Investigations.

\begin{tabular}{|l|l|l|}
\hline & Results & References \\
\hline$H b$ & $160 \mathrm{~g} / \mathrm{L}$ & $130-180 \mathrm{~g} / \mathrm{L}$ \\
\hline HbAlc & $9.6 \%$ & $4-6 \%$ \\
\hline Fasting blood glucose & $27.1 \mathrm{mmol} / \mathrm{L}$ & $3.5-7.7 \mathrm{mmol} / \mathrm{L}$ \\
\hline C-peptide & $1.0 \mu \mathrm{g} / \mathrm{L}$ & $0.8-3.4 \mu \mathrm{g} / \mathrm{L}$ \\
\hline Fasting insulin level & $6 \mathrm{mU} / \mathrm{L}$ & $<10 \mathrm{mU} / \mathrm{L}$ \\
\hline Anti-insulin antibody & Not detected & - \\
\hline $\begin{array}{l}\text { Glutamic acid } \\
\text { decarboxylase antibody }\end{array}$ & $5 \mathrm{U} / \mathrm{L}$ & $5 \mathrm{U} / \mathrm{L}$ \\
\hline Islet cell antibody & Not detected & - \\
\hline Zinc transporter 8 antibody & Not detected & - \\
\hline TSH & $8.1 \mathrm{mIU} / \mathrm{L}$ & $0.5-4.0 \mathrm{mIU} / \mathrm{L}$ \\
\hline Free thyroxine & $15 \mathrm{pmol} / \mathrm{L}$ & $10-20 \mathrm{pmol} / \mathrm{L}$ \\
\hline Thyroglobulin antibody & $<20 \mathrm{IU} / \mathrm{L}$ & $<40 \mathrm{IU} / \mathrm{L}$ \\
\hline Thyroid peroxidase antibody & $>1300 \mathrm{IU} / \mathrm{L}$ & $<60 \mathrm{IU} / \mathrm{L}$ \\
\hline Gliadin IgG antibody & $3 \mathrm{U} / \mathrm{mL}$ & $<20 \mathrm{U} / \mathrm{mL}$ \\
\hline TTG IgA antibody & $2 \mathrm{U} / \mathrm{mL}$ & $<24 \mathrm{U} / \mathrm{mL}$ \\
\hline
\end{tabular}

failure to achieve good glycaemic control on oral hypoglycaemic agents led to a diagnosis of antibody negative type 1 diabetes mellitus. Notably, there was no history of diabetic ketoacidosis or evidence of diabetes complications. His background history was significant for dyslipidaemia, gastroesophageal reflux disease and family history of autoimmune thyroid disease. Regular medications included basal-bolus insulin therapy, thyroxine, atorvastatin, pantoprazole and panadeine forte for his colicky abdominal pain. On examination, he weighed 79 kilograms and had a body mass index of $25.5 \mathrm{~kg} / \mathrm{m}^{2}$. Cardiorespiratory and gastrointestinal examinations were unremarkable.

Laboratory investigations in 2020 showed an HbAlc of $8.6 \%$. He was replete for micronutrients and fat-soluble vitamins, and was biochemically euthyroid. His full blood count, pancreatic enzymes and renal function were all within normal limits [Table 2]. Repeat C-peptide level was low $0.68 \mu \mathrm{g} / \mathrm{L}$ [0.8-3.4] with a paired blood glucose level of $11.4 \mathrm{mmol} / \mathrm{L}$. Agenesis of the dorsal pancreas was noted on CT imaging of the abdomen demonstrated agenesis of the dorsal
Table 2: Most recent laboratory results.

\begin{tabular}{|c|c|c|}
\hline & Results & References \\
\hline$H b$ & $154 \mathrm{~g} / \mathrm{L}$ & $130-180 \mathrm{~g} / \mathrm{L}$ \\
\hline$M C V$ & $78 \mathrm{fL}$ & $82-95 \mathrm{fL}$ \\
\hline $\mathrm{MCHC}$ & $346 \mathrm{~g} / \mathrm{L}$ & $300-350 \mathrm{~g} / \mathrm{L}$ \\
\hline \multicolumn{3}{|l|}{ Micronutrients } \\
\hline Iron & $24.4 \mu \mathrm{mol} / \mathrm{L}$ & $9-31 \mu \mathrm{mol} / \mathrm{L}$ \\
\hline Ferritin & $71 \mu \mathrm{g} / \mathrm{L}$ & $30-300 \mu \mathrm{g} / \mathrm{L}$ \\
\hline Transferrin saturation & $37 \%$ & $16-45 \%$ \\
\hline Folate & $24 \mathrm{nmol} / \mathrm{L}$ & $>10 \mathrm{nmol} / \mathrm{L}$ \\
\hline Vitamin $B_{12}$ & $205 \mathrm{pmol} / \mathrm{L}$ & $150 \mathrm{pmol} / \mathrm{L}$ \\
\hline Holocotransbalamin & $84 \mathrm{pmol} / \mathrm{L}$ & $51 \mathrm{pmol} / \mathrm{L}$ \\
\hline \multicolumn{3}{|l|}{ Exocrine function } \\
\hline Vitamin $A$ & $1.6 \mu \mathrm{mol} / \mathrm{L}$ & $1.4-4.0 \mu \mathrm{mol} / \mathrm{L}$ \\
\hline 25-OH Vitamin D & $68 \mathrm{nmol} / \mathrm{L}$ & $50 \mathrm{nmol} / \mathrm{L}$ \\
\hline Vitamin $E$ & $31 \mu \mathrm{mol} / \mathrm{L}$ & $8-30 \mu \mathrm{mol} / \mathrm{L}$ \\
\hline Vitamin $K$ & $0.5 \mathrm{nmol} / \mathrm{L}$ & $0.3-2.6 \mathrm{nmol} / \mathrm{L}$ \\
\hline Amylase & $43 \mathrm{U} / \mathrm{L}$ & $<115 \mathrm{U} / \mathrm{L}$ \\
\hline Lipase & $11 \mathrm{U} / \mathrm{L}$ & $<60 \mathrm{U} / \mathrm{L}$ \\
\hline Fecal elastase & $317 \mu \mathrm{g} / \mathrm{g}$ & $<100 \mu \mathrm{g} / \mathrm{g}$ \\
\hline \multicolumn{3}{|l|}{ Endocrine Function } \\
\hline Random glucose & $11.4 \mathrm{mmol} / \mathrm{L}$ & $3.5-7.7 \mathrm{mmol} / \mathrm{L}$ \\
\hline C peptide & $0.68 \mu \mathrm{g} / \mathrm{L}$ & $0.8-3.4 \mu \mathrm{g} / \mathrm{L}$ \\
\hline$H b A 1 c$ & $8.6 \%$ & $4-6 \%$ \\
\hline \multicolumn{3}{|c|}{ Complication screen in type 1 diabetes mellitus } \\
\hline TSH & $1.32 \mathrm{mIU} / \mathrm{L}$ & $0.4-3.5 \mathrm{mIU} / \mathrm{L}$ \\
\hline Free thyroxine & $12.8 \mathrm{pmol} / \mathrm{L}$ & 9-19 pmol/L \\
\hline Thyroglobulin antibody & $20 \mathrm{IU} / \mathrm{L}$ & $<60 \mathrm{IU} / \mathrm{L}$ \\
\hline Thyroid peroxidase antibody & $289 \mathrm{IU} / \mathrm{L}$ & $<35 \mathrm{IU} / \mathrm{L}$ \\
\hline TSH receptor antibody & $1.0 \mathrm{IU} / \mathrm{L}$ & \\
\hline Gliadin $\operatorname{Ig} G$ antibody & $4 \mathrm{U} / \mathrm{mL}$ & $<20 \mathrm{~mL}$ \\
\hline TTG IgA antibody & $1 \mathrm{U} / \mathrm{mL}$ & $<4 \mathrm{U} / \mathrm{mL}$ \\
\hline Total IgA antibody & $1.2 \mathrm{~g} / \mathrm{L}$ & $0.8-4.4 \mathrm{~g} / \mathrm{L}$ \\
\hline
\end{tabular}

pancreas. There were no focal pancreatic lesions or evidence of acute or chronic pancreatitis. This was confirmed on MRCP which also showed normal hepatobiliary anatomy [Fig.1]. His fecal elastase was $317 \mathrm{microg} / \mathrm{g}$ [>100 microg/g].

His abdominal pain improved with cessation of panadeine forte and good glycaemic control was achieved with up titration of his insulin therapy. 


\section{Discussion}

ADP is a rare congenital abnormality that arises from dysgenesis of the dorsal pancreatic bud. The dorsal endodermal bud forms the upper part of the head, body and tail of the pancreas, whilst the ventral bud develops into the posterior part of the pancreatic head, uncinate process and main pancreatic duct of the pancreas [2]. Strict signalling pathways regulate the fusion of the ventral and dorsal buds and subsequent morphogenesis and differentiation of multipotent progenitor cells into acinar, ductal and endocrine cells. The acinar and ductal cells comprise $99 \%$ of the pancreatic mass and fulfil the exocrine functions, whilst the islet cells of Langerhans comprise the remainder of pancreatic tissue. Associations between embryogenesis of the pancreas and genes such as HNF1B [3] and GATA6 [4], and signalling pathways such as retinaldehyde dehydrogenase 2 (Raldh2) [5] have been reported in the literature. Yet this condition remains rare with less than one hundred and twenty cases reported in the literature [6-9].

Most patients with ADP remain asymptomatic; it is often identified incidentally on abdominal imaging. However, if symptomatic, abdominal pain is the commonest symptom at presentation [1]. Abdominal pain among patients with ADP has been postulated to be due to pancreatitis, duodenal obstruction and sphincter of Oddi dysfunction [6]. Our patient had normal amylase and lipase levels and there were no features suggestive of acute or chronic pancreatitis on abdominal imaging. We noted that he was on panadeine forte for abdominal pain, and cessation of panadeine forte and commencement of paracetamol for abdominal pain resulted in improvement in abdominal pain. Panadeine forte contains codeine, which has been shown to increase the basal pressure of the sphincter of Oddivia the non mu opioid receptor and results in spasm of the sphincter of Oddi.

Patients with ADP can present with symptoms of endocrine and exocrine deficiency.
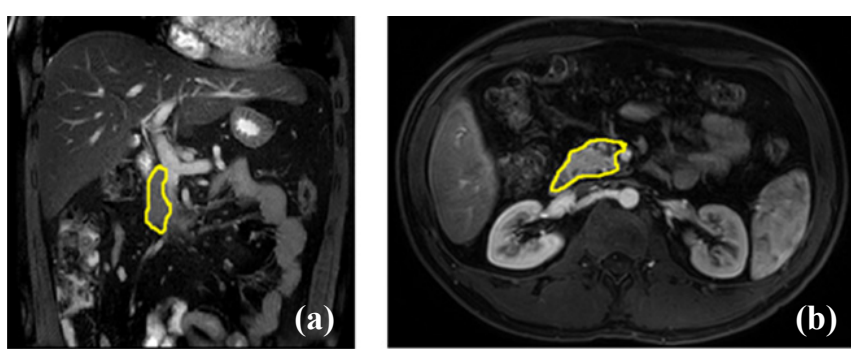

Fig.1(a): Coronal section (b): Axial section of Magnetic resonance cholangiopancreatography showing the head of pancreas (yellow) and the absence of the body and tail of the pancreas.

Approximately half of patients with ADP will develop diabetes mellitus, and up to half of them will require insulin therapy [7-9]. The age of onset of diabetes mellitus associated with ADP ranges between 28 to 39 years [7-9]. Although beta cell dysfunction and insulin deficiency have been implicated in the pathophysiology of diabetes mellitus among patients with ADP, there have only been three studies that reported a correlation between this congenital malformation and diabetic ketoacidosis [7,9]. Studies conducted on patients who have undergone surgical resection of the pancreas for other indications demonstrate that the pancreatic tail in humans is more densely populated with islets of Langerhans than other parts of the pancreas. Animal studies have shown functional differences in these islets based on their location, whereby islets originating from the dorsal pancreatic bud have greater capacity to secrete and synthesise insulin than islets of ventral bud origins [10]. These studies have shown that removal of the pancreatic tail led to elevated fasting glucose and post-challenge hyperglycaemia, whilst removal of the pancreatic head caused an improvement in oral glucose tolerance. Very few cases of ADP reported in the literature have paired C-peptide levels measured. Our patient had a low-normal C-peptide level of $1.0 \mu \mathrm{g} / \mathrm{L}$ [0.8-3.4] and serum insulin level of $7 \mathrm{mu} / \mathrm{L}[<10]$ with a paired random blood glucose level $27.1 \mathrm{mmol} / \mathrm{L}$ around the time of diagnosis, highlighting how variable degrees of $\beta$-cell dysfunction contribute to dysglycaemia among patients with agenesis of the dorsal pancreas. 
Steatorrhoea is a manifestation of exocrine deficiency and is commonly managed with supplementation of pancreatic enzymes. ADP has been associated with include polysplenia, ectopic spleen, bowel malrotation, horseshoe kidney, congenital heart disease and heterotaxy [7], none of which were noted on our patient's CT abdomen and MRCP. There has been an increased frequency of incidental diagnosis of ADP [6,7]. Abdominal $\mathrm{CT}$ assists in the diagnosis of ADP, and MRCP helps characterise the anatomy of the biliary ductal system [6].

\section{Conclusion}

ADP is often asymptomatic but can also present with abdominal pain or with features of exocrine and endocrine deficiency. It is often diagnosed incidentally on abdominal imaging.

Contributors: VM: manuscript writing, patient management; MVA: manuscript editing, patient management; EH: critical inputs into the manuscript. VM will act as a study guarantor. All authors approved the final version of this manuscript and are responsible for all aspects of this study.

Funding: None; Competing interests: None stated.

\section{References}

1. Cienfuegos J, Rotellar F, Salguero J, Benito A, Solórzano JL, Sangro B. Agenesis of the dorsal pancreas: systematic review of a clinical challenge. Revista Espanola de Enfermedades Digestivas. 2016;108:479-484.

2. Caetano LA, Santana LS, Costa-Riquetto AD, Lerario AM, Nery M, Nogueira GF, et al. PDX1-MODY and dorsal pancreatic agenesis: new phenotype of a rare disease. Clinical Genetics. 2018;93(2):382-386.

3. Schnedl WJ, Reisinger EC, Schreiber F, Pieber TR, Lipp RW, Krejs GJ. Complete and partial agenesis of the dorsal pancreas within one family. Gastrointestinal Endoscopy. 1995;42(5):485-487.

4. Lango Allen H, Flanagan SE, Shaw-Smith C, De Franco E, Akerman I, Caswell R, et al. GATA6 haploinsufficiency causes pancreatic agenesis in humans. Nature Genetics. 2012;44:20-22.

5. Li H, Arber S, Jessell TM, Edlund H. Selective agenesis of the dorsal pancreas in mice lacking homeobox gene Hlxb9. Nat Genet. 1999;23(1):67-70.

6. Kumar R, Vyas K, Agrahari N, Kundu J, Jaiswal G. Complete agenesis of the dorsal pancreas: case report with imaging findings and review of the literature. Malawi Medical Journal. 2015;27(2):73-74.

7. Yang T, Yang X, Wang L, Mo J. Agenesis of the dorsal pancreas presenting with diabetic ketoacidosis - a case report and literature review. BMC Endocrine Disorders. 2019;19:120.

8. Sonkar SK, Kumar S, Singh NK. Agenesis of dorsal pancreas in a young adult: a rare cause of diabetes mellitus. BMJ Case Reports. 2018.

9. Salman R, Barakat A, Berjawi G. Dorsal pancreatic agenesis in newly diagnosed type one diabetes mellitus: case report and review of literature. International Journal of Diabetes in Developing Countries. 2019;39:228-231.

10. Xavier GDS. The cells of the islets of Langerhans. Journal of Clinical Medicine 2018;7(3):54. 